\title{
Narrative of a drug user's daughter: impact on family daily routine
}

Narrativa de filha de usuária de drogas: repercussões no cotidiano familiar

\section{Narrativa de hija de usuaria de drogas: repercusiones en el cotidiano familiar}

Lúcia Margarete dos Reis ${ }^{1}$ Catarina Aparecida Sales ${ }^{1}$ Magda Lúcia Félix de Oliveira ${ }^{1}$

1. Universidade Estadual de Maringá

Maringá, PR, Brazil.
Corresponding author:

Lúcia Margarete dos Reis.

E-mail: luciamargarete@gmail.com

Submitted on $04 / 11 / 2017$.

Accepted on $06 / 15 / 2017$.

DOI: 10.1590/2177-9465-EAN-2017-0080

\section{Abstract}

Objective: To understand the repercussions of coexisting with the drug use in a family based on the daughter's narrative of a woman who is a multiple drugs user. Method: A case study with a family accessed in 2014, through the records of a Poison Control Center in the North of Paraná. It was used a semi-structured interview and field journal, and resources of thematic ora history to apprehend the story, from the question "How is/was for you and your family to live with a mother who is a drug user?" Results: The daughter's memories emphasized repercussions in the family context: long-term of living with drug abuse; absence or transience of the motherly figure, with rupture processes for homeless situation; cycle of parental disruption/forgiveness and continued presence and fatherly support. Final considerations: The narrative indicated a family that could be added to the process of rehabilitation and social reintegration of the female drug user.

Keywords: Family relations; Family conflict; Family Health; Street drugs; Public Health.

\section{Resumo}

Objetivo: Apreender as repercussões do uso de drogas na convivência de uma família, a partir da narrativa da filha de uma mulher usuária de múltiplas drogas. Método: Estudo de caso com família acessada, em 2014, através de registros de um Centro de Controle de Intoxicações do norte do Paraná. Entrevista semiestruturada, diário de campo e recursos da história oral temática para apreensão do relato foram utilizados a partir da questão "Como é/foi para você e sua família conviver com uma mãe usuária de drogas?". Resultados: As memórias da filha ressaltaram reflexos no contexto familiar: convivência por longo período com o abuso de drogas; ausência ou transitoriedade da figura materna, com processos de ruptura para situação de rua; ciclo de rompimento/perdão conjugal dos pais e presença contínua e apoio paterno. Considerações finais: A narrativa indicou uma família que poderia ser aliada do processo de reabilitação e reinserção social da mulher usuária de drogas.

Palavras-chave: Relações familiares; Conflito familiar; Saúde da família; Drogas ilícitas; Saúde Pública.

\section{Resumen}

Objetivo: Aprehender las repercusiones del uso de drogas en la convivencia de una familia, a partir de la narrativa de la hija de mujer usuaria de múltiples drogas. Método: Estudio de caso con familia accedida, en 2014, por medio de los registros de un Centro de Control de Intoxicaciones del norte de Paraná. Se utilizaron entrevistas semiestructuradas y diario de campo, y recursos de la historia oral temática para aprehensión del relato, a partir de la cuestión "¿Cómo es/fue para usted y su familia convivir con una madre usuaria de drogas?". Resultados: Según las memorias de la hija, la convivencia familiar por largo período con el abuso de drogas; la ausencia o transitoriedad de la figura materna en el domicilio, con procesos de ruptura para situación de calle; el ciclo de rompimiento/perdón conyugal de los padres, y la presencia continua y apoyo del padre, fueron resaltados como reflejos en el contexto familiar. Consideraciones finales: La narrativa indicó una familia que podría ser parcera para el proceso de rehabilitación y reinserción social de la mujer usuaria de drogas.

Palabras clave: Relaciones familiares; Conflicto familiar; Salud de la familia; Drogas ilícitas; Salud Pública. 


\section{INTRODUCTION}

The proportion of the phenomenon of drug use in Brazilian urban centers brings fear, insecurity and a sense of helplessness to families under this situation. The experience of living in a "drug use environment" affects the family group in the psychological, financial and social aspects, and, as evidence of this impact in these families, there are isolation and social vulnerability, family overload and illness of the ascending and descending family members of the drug user. ${ }^{1-3}$

With a deep impact on all social dimensions, drug abuse affects not only the user, but also all the elements of the family nucleus in an affective, economic and social way, as it implies a great cost to acquire the drug and wears out interpersonal and family affections and relationships. ${ }^{4}$ Drug addiction affects both the user and the family system, however the treatment of this condition is usually centered on the user, leaving the family in the background. ${ }^{5}$

A recent population-based study on the risk use of alcoholic beverage -comprised as one that can lead to dependence and social, economic and health problems - and associated and differenting factors between men and women, showed the prevalence of risk of alcohol consumption $9.5 \%$ in the studied area and signs of dependence and problems resulting from the use of alcohol in men. ${ }^{6}$ However, the alcohol and/or other drugs usage by women has been increasing in recent decades and the presence of alcohol consumption is identified with linear growth. ${ }^{7,8}$

Women tend to omit drug use, fearing social reprisals and stigma and remain anonymous, leading to undernotification and exclusion in health and social systems. ${ }^{7}$ Generally, they "demonstrate" their addiction through other signs, such as depression and irritability ${ }^{9}$ and might be found in Police stations, jails and prisons due to drug-related crimes or in hospitals, due to involvement in violent acts or because of health care needs for drug-related and non-drug-related conditions, and in rehabilitation services to treat drug addiction, in severe cases of dependence. ${ }^{10}$

Society, generally speaking, marginalizes drug users by attributing negative stereotypes associated with the disease, and drug use by women continues to be a taboo subject, in a "conspiracy of silence", in which talking about the needs and anguishes that involve these experiences is avoided. The problem of drug use and the repercussions on the family life of women, due to the strong bond between mother and child health, break the family boundaries and become a primary focus for the practice of nursing as a caring profession. ${ }^{11,12}$

The difficulty for the establishment of a nursing practice for the female user and her family is proportional to the scientific production on the subject of multiple drug abuse and family: the main focus is directed to the repercussions on health and the social and familiar relations of male users, due to the epidemiological exuberance of the difference of cases between the sexes, and those generally investigated are their mothers, sisters and wives. ${ }^{11-13}$
In this context, the study was conducted to discuss particular matters in the life trajectory of a family of a woman who is a drug user, given the scarcity of studies on the impact of abuse and the repercussions of drugs on family cohabitation. ${ }^{11}$ As a study question, it was suggested that drug users have a descending social trajectory and that the family induces and is influenced by their addiction, and, for the woman, this situation is even more worrisome, considering the invisibility of the problem related to drug abuse in the female population. It becomes relevant as it allows to give visibility to the phenomenon of drug use, allowing to think strategies of actions articulated and focused in the context of women's health.

Considering the relevance of the narrative as a tool for appropriating the family experience of chronic diseases, ${ }^{14}$ the objective of this study was to understand the repercussions of drug use on the coexistence of a family, based on the daughter's narrative of a woman who is a multiple drug user.

\section{METHODS}

This is a case study with a qualitative approach ${ }^{15}$ carried out with a family living in a city in the northern region of Paraná, consisting of six people at the time: the mother; the father; two brothers; a daughter and a grandson. Due to the worsening drug addiction, the mother no longer lives with the family.

The life history we will describe was told by a long term multi-drug user's daughter, an observer and informant of family relationships, invited to participate in the study, who agreed by signing the Free and Informed Consent Term and codified as "F1". While hospitalized in the Emergency Room of the Regional University Hospital of Maringá, the mother had been registered at the Intoxication Control Center, which is an information and toxicological assistance Center. This case was selected for the present study because it was the only case of a woman hospitalized after the occurrence of physical trauma associated with multiple drug abuse intoxication, and with family bond, hospitalized in the period from April to September 2014 in this hospital.

The aim of oral history is to capture and to record the life experiences of people and groups who are willing to testify or that are invited to translate their experience into written documents through speech. In its thematic aspect, being part of a specific subject, and by its direct objectivity, the peculiarities of the personal history are only of interest as one identifies aspects that may be useful to the central thematic information. ${ }^{14,16}$ In this sense, the referential of thematic oral history was used as a method of apprehending the daughter's narrative.

Data collection involved documentary analysis, with compilation of records from the Toxicological Occurrence File of the Poison Control Center, which contains identification data, the toxicological occurrence, the treatment performed, the clinical course and the outcome of the case of the intoxicated person, to enable the daily monitoring of cases; a phone approach to incite the family to their participation in the research and authorization to transform their experience into a written 
document, as well as choosing a member for the testimony and confirmation of the family home address; semi-structured narrative interview with a script for contextualizing and characterizing the user, daughter and family, with questions related to socioeconomic and demographic data, and the generating question: "How was it for you and your family to live with drug use by your mother?"; and, compilation of the field diary used for recording the researcher's perception about the social context, relationships, behaviors, questions, emotions, and perceptions of the researcher. ${ }^{17}$

Narrative as a methodological resource for research constitutes a favorable tool for understanding the memory and history of the subject involved in the proposed investigation. ${ }^{18}$ In the nursing field, narrative and thematic oral history, as scientific methods, seek to elucidate experiences lived under different contexts and allow to understand the construction of nursing care, training, life and community processes. ${ }^{14}$

The first contact with the family was made during the mother's hospitalization in the Emergency Room - ER. The clinical data of the intoxication due to multiple drug abuse and physical trauma, compiled from the ER Record and occurrence report, which resulted in hospital admission, through report of a non-family companion, were recorded in the Epidemiological Record of Toxicological Occurrence. After 48 days of hospital discharge, the telephone contact was made with the family and the daughter was indicated as a key informant.

After reading and acknowledging the data of the Epidemiological Record of Toxicological Occurrence, the interview with F1 was conducted in August 2014, in a single meeting at the family home. Recorded on digital media, it lasted 70 minutes and followed the steps: 1. Preparation - exploration of the research field; 2. Initiation - formulation of questions to characterize the family; 3. Central Narrative - formulation of the generating question; 4. Phase of Questions - development of questions on themes and topics brought by the informant and 5. Conclusive Speech - conclusion of the narrative. ${ }^{19}$

The data processing and analysis was adapted from Fritz Schütze ${ }^{20}$ who, besides presenting the proposal of the narrative interview, points out phases for the data systematization: detailed transcription of the verbal material; division of the text into indexed material (it has concrete reference to "who did what, when, where and why") and non-indexed (express values, judgments and all forms of life wisdom); use of the indexed components of the text to analyze the sequence of events; the non-indexed dimensions of the text are investigated as capture/knowledge production, with grouping and comparison between the individual trajectories and the context. ${ }^{19}$

This way, from F1 narrative, two dimensions were evidenced for analysis: a) history and trajectory: contextualization of events and b) feelings, experiences and thoughts generated by events.

All established ethical precepts were followed and the study was approved by the Research Ethics Committee Involving Human Beings of the State University of Maringá, under opinion 458.185/2013.

\section{HISTORY AND TRAJECTORY: CONTEXTUALIZATION OF EVENTS}

The daughter, 19 years old with 11 years of schooling, worked as an assistant doing general services in a restaurant, with work registration and Social Security. Although very young, the authors inferred through observation and records in the field diary that the daughter took over the "mother's role" and the responsibility of taking care of the family. As a teenager, at the age of 15 , she had a baby and used to attend a Catholic church, located near his home, once a week.

She lived in her own house, of five rooms, with her father, 51 years old, four years of schooling, who worked as a load unload truck assistant, with work registration and Social Security, and two brothers - aged 15 and 11 years old - both with a three-year school delay and her four-year-old son. The monthly family income was approximately $R \$ 2,100.00$, which corresponded, at the time of the interview, to 2.9 minimum wages.

Based on the characteristics of the family, the profile is similar to that of the Brazilian general population, according to results from the National Survey by Household Sample - PNAD, which indicated that $74.7 \%$ of families live in their own homes and $47.5 \%$ has a monthly per capita income of up to $\mathrm{R} \$ 678.00$, corresponding to a monthly family income of approximately $\mathrm{R} \$ 2,000.00 .^{21}$

However, in this family, factors that characterize it as a vulnerable family are highlighted: a) the school delay of the children, since the vicious cycle of repetition and school dropout may imply less insertion in the formal labor market; b) mother's unemployment; c) low financial resource and, consequently, greater vulnerability to drug abuse; ${ }^{22} \mathrm{~d}$ ) teenage pregnancy and the difficult process of adaptation to this unplanned and unexpected situation; $\mathrm{e}$ ) the daughter's overload due to the double working hours and care for the family and f) the neighborhood with risk situations for drug use, due to the flow of drugs observed by the researchers who could feel smell of marijuana when passing by the house next door, confirming the daughter's report that "they always use drugs near their home".

The mother (49), with eight years of schooling, never worked with registration and Social Security and used multiple drugs alcohol, tobacco, marijuana, crack cocaine. According to the daughter, the mother drinks alcohol, uses tobacco and marijuana for 25 years, and has been using crack for 10 years.

Not only aspects of education and access to work were affected. The daughter reported that the mother presented risky sexual behavior, with relationships outside marriage, multiparity and abortions, discontinuance of the marital bond, homeless situation and pregnancy of an "unknown father". At the time of the research, she was living with a boyfriend, near the family home, however, she also kept a homelessness situation.

The long term pattern of multiple drug use was decisive in this woman's life, culminating in disqualification for the job market, since she was never formally able to work due to the effects of drug abuse. It is an adult woman who had her life trajectory defined by the use of drugs. 
The pattern of drug use is a central issue in the lives of users, because when there is no control over consumption, the consequences begin to invade and affect various areas of life, worsening quality of life and social relationships, leading to the narrowing of social coexistence. ${ }^{2}$ Multiple drug addiction is a disease that can lead to individual and functional limitations, as well as other negative impacts on social interaction, whether personal or professional. In addition, it significantly affects the health and quality of life of users and their families. ${ }^{23,24}$

Women introduced changes in the culture of drug use, especially regarding to sexual behavior. Lack of financial conditions can lead them to engage in unlawful activities and unprotected sexual intercourse in exchange for drugs or money, making them subject to the risk of unwanted pregnancy and sexually transmitted diseases. ${ }^{25}$

The records in the Epidemiological Record of Toxicological Occurrence indicated that the user was admitted to the Emergency Room, transported by the Integrated Emergency Care Service - SIATE, after being found "sitting on the sidewalk" after physical aggression (with a piece of wood) in a bar near home.

This occurrence was registered in the Poison Control Center, having as toxic agent the alcoholic beverage. The effects of intoxication recorded were alcoholic breath and zygomatic bone fracture, as secondary trauma to acute chronic intoxication. The woman was discharged from hospital after being hospitalized for four days, returning to her boyfriend's house without keeping touch with her children. The trauma was considered moderate, however there were reports of several previous episodes of physical aggression.

Although multiple drug abuse has been reported as a drug use pattern in the life trajectory, the occurrence of physical aggression trauma was only associated with the use of alcoholic beverage. Alcohol, in particular, is a drug that produces a twophase effect in humans, that is, it has euphoric and depressant action. The main characteristic of this consumption is the alteration of the physical and psychic state, with behavioral reactions that include compulsion by the continuous or periodic ingestion of the substance, which can lead to situations of violence. ${ }^{24,26}$

\section{FEELINGS, EXPERIENCES AND THOUGHTS GENERATED BY EVENTS}

Initially, the narrative of the daughter allowed the approach to the context of beginning and continuity to the drug use. The onset of the use is confused with repeated episodes of homless situation, alternating stability, crisis and instability, from the compulsive use of drugs and periods of abstinence.

Her life was very messy, her mother abandoned her and she was raised by her grandmother [...] after a while her grandmother moved out from São Paulo and she started to live in the street in the big city. Then she went to live in a shelter, but ran away to the streets [...] She suffered a lot of violence [...]. (F1)

I think she started using drugs because of not having a family. She has been using drugs since adolescence. She uses crack, marijuana, alcohol, and cigarettes. There are times when she stays weeks without using, but there are times when she uses every day. (F1)

When she drinks she becomes a very annoying and fierce person. The day she was hospitalized, she started to cause troube, so they started to fight her. Some have said one thing and some say others. I'm not sure what happened. They found her lying on the street, passed out and took her to the hospital [...] she always got into fights, it happened several times before. She drinks and gets very annoying, so she $s$ always fighting. (F1)

The lack of a family structure, characterized by the abandonment of parents, added to the approach to drug abuse by the condition of homelessness were the factors that contributed substantially to the beginning of drug use and the negative changes in the life F1's mother. The daughter reported certain events in the mother's life history as a way to justify and forgive the drug use, conforming an explanatory model about the mother's drug use, such as problematic childhood, stressful events or traumas in childhood, abandonment and the discovery of drugs.

The complexity of the factors that lead to the onset of drug use and the development of addiction are influenced by situations experienced in the history by the person. The greater the number of unfavorable experiences in childhood and adolescence, the greater is the proportion of psychosocial problems in adult life. ${ }^{5,27}$ In addition, the lack of social support - network health care, employment and support for the family - and the difficulty in accessing and linking health services, have contributed to the worsening of the drug use situation. ${ }^{28}$

Regarding violence in childhood and adolescence, as an indicator of the severity of drug use, a significant number of drug users who experienced some traumatic event in the first years of life presented precocity in the first use and experimentation of several drugs in relation to subjects who experienced only traumatic experiences in adulthood. According to psychosocial studies, the earlier the trauma experience, the more premature it could be the first contact with the multiple drugs considered as a "gateway", such as alcohol and marijuana, although this effect may also be associated with crack cocaine. ${ }^{27,29}$

The daughter reported violence and stressful events that negatively marked the life trajectory of her mother and significantly affected her family - the behavioral change repeated at short intervals by the mother and her aggressiveness and hostility, leading to psychological and physical intrafamily violence and to the consequent compromise of family structure. 
My father met her on the street. It has been twelve years that she and my father have separated and she always drank [...] they were together only because of the children. They have nothing else together, for about 15 years now, since when my sister was born. (F1)

My brother is not my father's son, he is from another relationship of hers and my father raised him. (F1)

I know that her boyfriend is also involved in fights[...] I saw him on the street and I know he also uses drugs, but I never talked to him. (F1)

The trajectory of the family was marked by several episodes of marital disruption. The narrative of the daughter denotes that the mother leaves and returns from her home and her family, a safe reference for housing. The profile of prolonged use, permeated by abstinence and relapse with lack of rehabilitation strategies, seems to determine the affective and marital life of the mother. Three events were relevant to the discontinuation of the family relationship: aggressive behavior when using drugs; recurrence of involvement in violent acts and illegal maneuvers to acquire the drug.

Before that day (hospitalization in the ER), there were other situations [...] many other aggressions and hospitalizations. I've seen her hurt several times. She is always in a fight, she would not know how many times she has been hospitalized. (F1)

It has been a while since she does not live with us anymore. But it was always like this: she stays a while here and a while on the street, using drugs [...] I do not know how she buys the drugs, but I think she steals. She asks my father for money to buy things for her and for the house, but sometimes she spends on drugs. (F1)

She knows how to control the use, but she is not ashamed ... she never sold anything from the the house ... I think that for her to stop using drugs, she would have to want it. These days my father wanted to pay for a treatment, but she did not accept it. We do not seek help from the health care unit because she will not go. She has help, but she does not want to stop, she does not have the will, because deep down inside she knows that it messes up her life. (F1)

Studies with the purpose of knowing the meaning and repercussions of the drug use by women, from their life histories, have identified that these women suffer several types of violence in their social context, which favors negative events in their lives. In daily life of users, social violence is one of the elements that negatively impact the health of these people ${ }^{25,28}$ and previous violence can be pointed as factors for the continuation of the phenomenon. ${ }^{30}$
The economic difficulty due to drug addiction, the difficulty in keeping a job and the inevitable social rupture, lead drug users to use illegal maneuvers with the family - recurrent lies and stealing and with the community of cohabitation - thefts and prostitution. These situations are common among testimony of drug users who, after breaking family ties, begin to live in homelessness, in marginality and social exclusion. ${ }^{25}$

At times, there was a contradiction in the daughter's narrative regarding her mother's drug use, because at the same time she understands and intends to help the mother, perhaps because of the support she finds in religion, the daughter does not accept the use of drugs and the risk behaviors of the mother, leading to a distance in order to survive and to be protected from the repercussions of the mother's drug use.

There was intense suffering in her daughter's narrative regarding to her mother's living conditions. In affirming that she never had the presence of the mother and that she has no contact with her, the daughter said that she grieves her mother's situation because she does not accept the use of drugs and believes that the use is related only to the mother's lack of motivation to stop using, compromising even more the family relationship, for blaming the mother for drug abuse.

I grew up watching my mother using drugs [...] I do not have the presence of a mother, as I see in other families out there [...] I do not have the mother's attention [...] I never had it. (F1)

In my opinion, living with the use of drugs by my mother is very bad because I did not want to see her like that, I wanted her to be different [...] I do not like that she uses drugs, I always suffered from it [...] my brothers accept it a little more, but I think they also struggle. (F1)

She hasn't been living here for a year now, but I always see her, but I have not talked to her in five months[...] I just knew she got beaten up because the other people told me. (F1)

To feel better about this situation, I try to comfort myself in God and I am very attached to my son. The affection I did not have with her, I give to him. (F1)

My father is very closed and I never could talk about certain things. Sometimes he gives me support [...]. (F1)

After the last traumatic event, the daughter did not attempt a rapprochement, obtaining information about the mother with relatives and neighbors. The mother always had several family conflicts, causing the loss of bond with the daughter and this situation worsens with each new episode of aggravation of the case, in addition, there were no changes in the behavior of the mother after the last hospitalization. The devastating consequences of drug use in this family commited to the maternal bond, generating intense suffering for the daughter, who shows with her teary eyes the absence of the motherly figure in her life trajectory. 
Healthy family relationships, since the birth of the child, is a protective factor for life and these relationships are not preserved in the family. Bonding and healthy family interaction are the foundation for the full development of a person's potentialities. ${ }^{27}$ Drug abuse is not a phenomenon with consequences only for one family member, but for the whole family group, and also occurs in the subjective perspective, causing negative feelings like tension, stress, worry, stigma, anger and guilt.

In addition, the daughter talked about coping strategies against her mother's drug use. In this sense, it was possible to measure the importance of religiosity, maternal and paternal figure for the adjustment of the family. These factors seem to be positive towards the problems faced in the family everyday due to the abuse of drugs by the mother.

The father/ex-husband/husband is a key figure in the understanding process and family cohesion. He has been present in his wife's life history since he met her out in the street and has been trying to get her out of the streets and drugs, as well he is motivated to seek help from outside the family to cope with drug use, although the user refuses the treatment. Besides, the repercussions of drug abuse in the family made the father assume the role of caregiver and educator of the children and grandson. The daughter reports that the father is the "support of the family," although the absence of the maternal figure has become evident in the narrative.

Family members relied on the paternal reference and on religious entities, as an informal support network, this allowed the maintenance of the principles of the family institution, as a protector and responsible for its members and the strengthening to face problems related to drug abuse in the context of family. In this sense, it is possible to say that however problematic the use of drugs for the family is, it can find internal resources to deal with the problem. Listening to the daughter's narrative, it was evident that the talk provided relief and sense of care to the daughter over the mother's drug abuse situation.

\section{FINAL CONSIDERATIONS}

Although this is a single case, from an individual perspective, the work carried out showed repercussions on the structure and family experience, due to the long period of living with drug abuse, showing the existing family relationships within a wider context. In this context, the narrative was constructed, dialogically to describe experiences shared by family members. Still, the interview in the home environment allowed an approach with the context of family life narrated by one of its members.

According to the daughter's memories, it is possible to emphasize as memories of the use of drugs, in the family context, the family's long-term relationship with drug abuse, the absence or transience of the maternal figure at home, with rupture processes for homelessness situation, the cycle of parental disruption/forgiveness and the continued presence and support of the father.
The uniqueness of the report seems to deconstruct the paradigm of the intergenerational pattern of drug use, from the unstructured, negligent family and cause of the continuity of drug use, to a family that could be allied with the care and partnership in a rehabilitation process if it were accessed by inclusive and innovative public policies.

Among the areas of knowledge and the professions in the health area, Nursing stands out for developing and producing activities related to the care, promotion, prevention and recovery of health and the nurse, inserted professionally in all levels of attention to the health, has the important role of identifying situations of vulnerability related to drug use. In this sense, the nurse, as a member of the multidisciplinary health team and responsible, mostly, for both primary health care actions and specific mental health actions, should act integrally in the care of the families of the drug users, in order to prevent the aggravation of the case and facilitate access to health care and social assistance to combat drug abuse in society.

\section{REFERENCES}

1. Filizola CLA, Perón CJ, Nascimento MMA, Pavarini SCI, Petrilli Filho F. Compreendendo o alcoolismo na família. Esc Anna Nery [Internet]. 2006 Dec; [cited 2017 Apr 11]; 10(4):660-70. Available from: https:// dx.doi.org/10.1590/S1414-81452006000400007

2. Copello A, Templeton L, Powell J. The impact of addiction on the family: estimates of prevalence and costs. Drugs Educ Prev Policy [Internet]. 2010 Dec; [cited 2017 Apr 11]; 17(Suppl.1):63-74. Available from: http:// www.scopus.com/inward/record.url?scp=78649235226\&partnerlD=8 YFLogxK

3. Laranjeira R, Sakiyama H, Padin MFR, Mitsuhiro R, Madruga CS, orgs. Levantamento nacional de famílias dos dependentes químicos. São Paulo: Instituto Nacional de Ciência e Tecnologia para Políticas Públicas de Álcool e Outras Drogas (INPAD). UNIFESP; 2013. [cited 2017 Apr 3]. Available from: http://inpad.org.br/wp-content/uploads/2013/11/ PressFamilia.pdf

4. Templeton L, Copello A. Adult Family Members Affected by a Relative's Substance Misuse: A Review of Policy and Guidance Documents across the UK. London: UK Drug Policy Commission; 2012. 42 p. [cited 2017 Apr 3]. Available from: http://www.ukdpc.org.uk/wp-content/ uploads/adult-family-members-affected-by-a-relative $\%$ E2\%80\%99ssubstance-misuse-a-review-of-policy-and-guidance-documentsacross-the-uk.pdf

5. Denning P. Harm reduction therapy with families and friends of people with drug problems. J Clin Psychol [Internet]. 2010 Feb; [cited 2017 Apr 11]; 66(2):164-74. Available from: http://harmreductiontherapy.org/ wp-content/uploads/2014/11/Families-Harm-Reduction.pdf

6. Francisco PMSB, Bastos TF, Costa KS, Prado MAMB, Barros MBA The use of medication and associated factors among adults living in Campinas, São Paulo, Brazil: differences between men and women. Ciênc Saúde Coletiva [Internet]. 2014 Dec; [cited 2017 Apr 11]; 19(12): 4909-21. Available from: http://dx.doi.org/10.1590/1413812320141912.18702013

7. Wolle CC, Sanches M, Zilberman ML, Caetano R, Zaleski M, Laranjeira $\mathrm{RR}$, et al. Differences in drinking patterns between men and women in Brazil. Rev Bras Psiquiatr [Internet]. 2011 Dec; [cited 2017 Apr 11]; 33(4):367-73. Available from: http://dx.doi.org/10.1590/S151644462011000400010

8. World Health Organization. Global status report on alcohol and health 2011. Genebra:World Health Organization; 2011 [Internet]. 2011; [cited 2017 Apr 11]. Available from: http://apps.who.int/iris/bitstream/10665/ 44499/1/9789241564151eng.pdf?ua=1 
9. Oliveira GC, Dell'Agnolo CM, Ballani TSL, Carvalho MDB, Pelloso SM. Consumo abusivo de álcool em mulheres. Rev Gaúcha Enferm [Internet]. 2012 Jun; [cited 2017 Apr 11]; 33(2):60-8. Available from: http://www. scielo.br/pdf/rgenf/v33n2/10.pdf

10. Marangoni SR, Oliveira MLF. Women users of drugs of abuse during pregnancy: characterization of a series of cases. Acta Sci Health Sci [Internet]. 2015 Jan/Mar; [cited 2017 Apr 11]; 37(1):53-61. Available from: http://periodicos.uem.br/ojs/index.php/ActaSciHealthSci/article/ view/16754/pdf_71

11. Santos AM, Silva MRS. The experience of caring for an alcoholic woman in the family. Rev Esc Enferm USP [Internet]. 2012 Apr; [cited 2017 Apr 11]; 46(2):364-71. Available from: http://dx.doi.org/10.1590/S008062342012000200014

12. Mula JM, Sánchez DH, Álvarez ES, Aragón FC; Grupo de Investigación Balear de Enfermería en Drogodependencias. Impacto de las actitudes de las enfermeras en la calidad de los cuidados en drogodependientes. Index Enferm [Internet]. 2012 Dec; [cited 2017 Apr 12]; 21(4):214-8. Available from: http://dx.doi.org/10.4321/S1132-12962012000300008

13. Assis DFF, Castro NT. Alcoolismo feminino: inicio do beber alcoólico e busca por tratamento. Textos Contextos [Internet]. 2010 Aug/Dec; [cited 2017 Apr 11]; 9(2):358-70. Available from: http://revistaseletronicas. pucrs.br/ojs/index.php/fass/article/view/7260

14. Macêdo MLAF, Costa MCMDR, Lima SP, Padilha MI, Borenstein MS. Thematic oral history in nursing research: a bibliometric study. Cogitare Enferm [Internet]. 2014 Apr/Jun; [cited 2017 Apr 11]; 19(2):360-7. Available from: http://www.revenf.bvs.br/scielo.php?script=sci arttext\&pid=S1414-85362014000200025\&lng=es

15. Yin RK. Estudo de Caso: Planejamento e Métodos. $4^{a}$ ed. Porto Alegre: Bookman; 2010.

16. Meihy JCSB, Holanda F. História Oral: Como Fazer, Como Pensar. São Paulo: Contexto; 2010.

17. Minayo MCS. O desafio do conhecimento: pesquisa qualitativa em saúde. $12^{\mathrm{a}}$ ed. São Paulo: Hucitec; 2010.

18. Rollemberg ATV. Histórias de vida de duas professoras: narrativas como instrumento de construção da identidade profissional. In: Lopes LPM, org. Discurso de Identidades: discurso como espaço de construção de gênero, sexualidade, raça, idade e profissão na escola e na família. Campinas: Mercado das letras; 2003.

19. Jovchelovitch S, Bauer MW. Entrevista narrativa. In: Bauer MW, Gaskell $\mathrm{G}$, orgs. Pesquisa qualitativa com texto e imagem: um manual prático. 9aㅡ ed. Petrópolis: Vozes; 2011. p. 90-113.

20. Schütze F.Die Technik des narrativen Interviews in Interaktionsfeldstudien: dargestellt an einem Projekt zur Erforschung von kommunalen Machtstrukturen. Bielefeld: Universität Bielefeld, Facultät für Sociologie; 1977. $62 \mathrm{p}$
21. Instituto Brasileiro de Geografia e Estatística - IBGE (BR). Pesquisa nacional por amostra por domicílios: síntese de indicadores 2013. [Internet] 2013; [cited 2017 Apr 11]. Available from: http://biblioteca. ibge.gov.br/visualizacao/livros/liv94414.pdf

22. Feltran GS. Valor dos pobres: a aposta no dinheiro como mediação para o conflito social contemporâneo. Cad CRH [Internet]. 2014 Sep/ Dec; [cited 2017 Apr 11]; 27(72):495-512. Available from: http://dx.doi. org/10.1590/S0103-49792014000300004

23. Fischer B, Cruz MS, Bastos FI, Tyndall M. Crack across the Americas A massive problem in continued search of viable answers: Exemplary views from the North (Canada) and the South (Brazil). Int J Drug Policy [Internet]. 2013 Nov; [cited 2017 Apr 11]; 24(6):631-3. Available from: http://dx.doi.org/10.1016/j.drugpo.2013.09.003

24. Carneiro ALM, Rodrigues SB, Gherardi-Donato ECS, Guimarães EAA, Oliveira VC. Padrão do uso de álcool entre estudantes universitários da área de saúde. Rev Enferm Cent Oeste Min [Internet]. 2014 Jan/Apr [cited 2017 Apr 11]; 4(1):940-50. Available from: http://www.seer.ufsj. edu.br/index.php/recom/article/view/449

25. Marangoni SR, Oliveira MLF. Uso de crack por multípara em vulnerabilidade social: história de vida. Cienc Cuid Saude [Internet]. 2012 Jan/Mar; [cited 2017 Apr 11]; 11(1):166-72. Available from: http:// dx.doi.org/10.4025/cienccuidsaude.v11i1.18874

26. United Nations Office on Drugs and Crime. World Drug Report; Vienna: United Nations Office on Drugs and Crime; 2015. [cited 2017 Apr 11] 162 p. Available from: https://www.unodc.org/documents/wdr2015/ World_Drug_Report_2015.pdf

27. Hines DA, Douglas EM. Alcohol and drug abuse in men who sustain intimate partner violence. Aggress Behav [Internet]. $2012 \mathrm{Jan} / \mathrm{Feb}$; [cited 2017 Apr 11]; 38(1):31-46. Available from: https://www.ncbi.nlm.nih.gov/ pmc/articles/PMC3315600/

28. Fertig A, Schneider JF, Oliveira GC, Olschowsky A, Camatta MW, Pinho LB. Women crack users: knowing their life stories. Esc Anna Nery [Internet]. 2016 Apr/Jun; [cited 2017 Apr 11]; 20(2):310-6. Available from: http://www.scielo.br/scielo.php?script=sci_arttext\&pid=S1414$81452016000200310 \&$ Ing $=e n \& n r m=i s o$

29. Laranjeira R, org. II Levantamento Nacional de Álcool e Drogas. São Paulo: Instituto Nacional de Ciência e Tecnologia para Políticas Públicas de Álcool e Outras Drogas (INPAD), UNIFESP;2012. [cited 2017 Apr 3] Available from: http://inpad.org.br/wp-content/uploads/2014/03/LenadII-Relat\%C3\%B3rio.pdf

30. Gadoni-Costa LM, Zucatti APN, Dell'Aglio DD. Violência contra a mulher: levantamento dos casos atendidos no setor de psicologia de uma delegacia para a mulher. Estud Psicol [Internet]. 2011 Apr/Jun; [cited 2017 Apr 11]; 28(2):219-27. Available from: http://dx.doi.org/10.1590/ S0103-166X2011000200009 